\title{
Insulation materials for buildings - a successful research \& development collaboration for the Romanian wool fibres manufacturing
}

PYERINA-CARMEN GHIȚULEASA

DOI: 10.35530/IT.069.05.1579

CEZAR BULACU

EFTALEA CĂRPUS

ANA ENCIU

ANGELA DOROGAN

EMILIA VISILEANU

\author{
REZUMAT - ABSTRACT
}

\section{Materiale izolatoare pentru construcții - o colaborare de success în domeniul cercetării și dezvoltării pentru producerea fibrelor de lână din România}

În contextul dezvoltării durabile, sectorul textil constituie un pilon puternic al industriei românești, în măsură să contribuie la valorificarea materiilor prime naturale autohtone. Lucrarea prezintă aspecte economice, în baza rezultatelor obținute în cadrul unui proiect finanțat prin programul Sectorial, al Ministerului Cercetării și Inovării, pentru valorificarea fibrelor de lână, românești, în scopul obținerii de materiale termo și fono-izolatoare, pentru construcții. Se evidențiază rezultatele colaborării, din cadrul proiectului, a trei actori importanți, din activitatea de cercetare și mediul economic: Institutul Național de Cercetare-Dezvoltare pentru Textile și Pielărie - INCDTP București - unicul institut de cercetare din domeniul textile-pielărie din țară, compania S.C. MINET S.A. Râmnicu Vâlcea - companie reprezentativă pentru industria nețesutelor din România și Institutul de Cercetare-Dezvoltare pentru Creșterea Ovinelor și Caprinelor - Palas, Constanța, parteneri în cadrul consorțiului coordonat de Institutul Național de Cercetare-Dezvoltare in Construcții, Urbanism și Dezvoltare Teritorială Durabilă - URBAN INCERC București.

Cuvinte-cheie: fibre de lână românești, inovare, eficiență, inițiative antreprenoriale, textile tehnice pentru construcții

Insulation materials for buildings - a successful research \& development collaboration for the Romanian wool fibres manufacturing

Having in view the sustainable development context, the textile sector represents a strong pillar of the Romanian manufacturing industry, which is able to contribute to the valorization of natural indigenous raw materials. The paper presents economic aspects in the base of the results obtained through developing/ implementing a research project financed by the National Sectorial Program, coordinated by the Romanian Ministry of Research and Innovation, aiming to establish strategic solutions for capitalization of Romanian coarse wool fibers. There are emphasized the project's results obtained by the collaboration of three important actors from research activity and economic environment: the National Research and Development Institute for Textiles and Leather - INCDTP Bucharest, the only R\&D Institute in Romania, SC MINET SA Company, Râmnicu Vâlcea county - a representative manufacturing company for nonwoven materials and the Research Institute for Sheep and Goats Breeding, Palas, Constanța county, partners in the consortium coordinated by the National Research and Development Institute in Constructions, Urban Planning and Sustainable Spatial Development URBAN-INCERC Bucharest.

Keywords: Romanian wool fibres, innovation, efficiency, business entrepreneurial initiatives, technical textiles for buildings

\section{INTRODUCTION}

Romania's rural development strategy for the coming years is in line with the EU's reform and development context with the Europe 2020 strategy [1]. Following the objectives of the Europe 2020 strategy for a smart, sustainable and inclusive economy, the strategy sets ambitious targets for Member States in the areas of education, innovation, energy/environment, employment and social inclusion and improving competitiveness in general [2].

The National Rural Development Program (NRDP) 2014-2020 [3] contributes to smart growth by supporting forms of cooperation between research institutions and farmers and other actors in the rural economy, but also by supporting training, skill acquisition and dissemination of information. The NRDP also envisages a sustained growth that focuses on lowering carbon emissions and supporting environment-friendly farming practices. Last but not least, support for investment in the infrastructure and the rural economy leads to poverty reduction and job creation in rural areas, thus contributing to an inclusive growth.

All these objectives will be possible to materialize only under the conditions of efficient utilization of indigenous raw materials, among which wool fibers, a valuable source both for the textile industry and for related sectors, as is the field of ecological constructions.

The wool processing sector in Romania experienced a regression in terms of fiber quality after 1989, caused by a combination of factors:

- uncontrolled crossbreeding, 
- low area,

- low quality pastures,

- lack of support for sheep breeders.

As a result, the spin ability limit of the Romanian wool has decreased, as well as the possibility of using it in the textile industry, in the conditions of increasing demand for fine woven and knitted fabrics and knitwear, leading to the closure of many traditional textile companies and the use of imported wool. Under these circumstances, the use of the Romanian wool for related fields such as construction, cosmetics, pharmaceuticals is much more important, as an efficient and viable alternative for recovery and an alternative for revitalization of several economic sectors.

Analysis of the construction materials market shows an increased interest in the use of wool as a thermal insulation material, leading to an economically significant impact, as the construction sector is a major energy consumer within the European Union, accounting for $40 \%$ of the total energy consumption and $36 \%$ of greenhouse gas emissions [4].

In this context, the Ministry of Research and Innovation in Romania, together with the Ministry of Agriculture, had the initiative to launch a competition for a project entitled "Research on the Development of Capacity for Transfer and Marketing of Research Results on Integrated Exploitation of Natural Wool Resources. Applicability of EcoInnovative Products Based on Sheep Wool in the Field of Constructions", in September 2017.

A multidisciplinary consortium consisting of representative research centers of industries such as textile INCDTP Bucharest, mechanics - ICTCM Bucharest, chemical-pharmaceutical research - ICCF Bucharest, sheep breeding - ICPCOC Palas Constanta, SC MINET SA RâmnicuVâlcea, SC IRECSON SA under the coordination of INCD URBAN-INCERC Bucharest ensured the critical mass of specialists in order to achieve the objectives of this project, ongoing in 2018.

The paper presents aspects regarding the textile valorization of the thick Romanian wool varieties in order to produce materials with the role of insulation and sealing, in the field of constructions.

\section{EXPERIMENTAL WORK}

At present, the proportion of "Turcană" breed sheep is over $70 \%$ of total heads, and of the wool volume after shearing, respectively.

The matrix of technological experimentation took into account the following experimental criteria:

- exploiting the technological equipment of the industrial partner SC MINET SA RâmnicuVâlcea; thus two distinct technologies were used in processing: i) consolidation the fibrous material by athermochemical process and ii) mechanical consolidation;

- the use of Turcana wools in particular; thus the fiber composition variants used were: a) $85 \%$ Turcana wool $+15 \%$ heat-activated adhesive fibers, b) $70 \%$ Turcana wool $+30 \%$ heat-activated adhesive fibers - processed, using technology i), and c) $100 \%$ Tigaie wool - processed using technology ii), respectively;

- adaptation of technological parameters and processing stages to the characteristics of the blended fibrous material;

- the coverage, according to the adjustment parameters, of the entire range of non-woven structures, possible to be obtained, on the used processing technologies;

- design and fabrication of nonwoven fabrics with different massdensity and thickness, covering a wide range, possible to be used by the constructors in different ways and locations of a building: floor, roof, walls;

- providing improved properties to the materials by applying functional treatments specific to insect/ moth protection, flame maintenance and propagation.

The highlighted innovative aspects are the subject of patent application A/10034/2018 of July 30, 2018, entitled "Unconventional textile fabric based on wool, from Romanian breeds, for the isolation of constructions and the process of obtaining thereof", authored by SC MINET SA, INCDTP, INCD URBAN-INCERC and ICPCOC Palas.

\section{ASPECTS REGARDING THE ECONOMIC EFFICIENCY}

The use of thick and semi-thick wools for the production of non-woven textile materials for the sound and thermal insulation of buildings is a high-potential entrepreneurial area, in the context of rising electricity, thermal and energy prices, and in the context of national and European trends in green building.

These are the arguments for which we analyzed the economic efficiency of capitalizing Romanian wools by simulating a family entrepreneurial business, that is, a minimal investment, possible to be achieved at the level of young Romanian entrepreneurship.

The working hypotheses (input data) we started in this simulation are:

- we are located in a mountainous rural area, where sheep breeding is a basic occupation of most peasant farms;

- the sheep wool is sheared once a year and the raw (greasy) wool obtained is collected and sent to a collection center (already existing in the country) to be forwarded to the wool laundry;

- the wools will be washed either at the wool laundry at SC STOFE SA Buhuși, or in cooperation with the laundries in Turkey;

*Observation: INCDTP highlights that an investment to set up a wool laundry is extremely costly, and involves the existence of waste water treatment plants, since it is a water impurifier; considering environmental regulations, we do not consider the possibility of washing small quantities of wool directly into rivers;

- entrepreneurial initiative starts basically from the processing of washed wools; 
- we also believe that the entrepreneur already owns the space and construction to open this microenterprise for the processing of washed wools and the production of non-woven textiles for thermal and sound insulation of buildings.

Taking into account these working hypotheses, a simulation of a business plan, based on the technical data obtained in the technological experiments carried out within the project, was conducted by SC MINET SA and INCDTP.

Based on cost categories, the situation is the following:

- raw material costs (lei/kg of washed wool); costs of chemical auxiliaries used in processing, anti-insect treatment products, fire retardance treatment products (lei/kg);

- labor costs: (lei/m² of non-woven fabric);

- utilities costs (overheads) (lei/m² of non-woven fabric);

- third-party processing: testing raw material and finished products, product research and development, marketing costs, as it is a starting entrepreneurial initiative.

The production prices ranged between 19.27-37.34 lei $/ \mathrm{m}^{2}$, varying directly in proportion to the specific consumption values $\mathrm{g} / \mathrm{m}^{2}$ and depending on the type of washing of the raw wools used (washing it abroad is more expensive).

It should be stressed that not only the low price aspects must be considered, but first of all the following should be taken into account:

- the technology allows the recovery of Romanian thick and semi-thick wool fibers, a raw material which does not have suitable spin ability characteristics for processing high fineness yarns and which is currently either burned or exported as raw material or collected in peasant farm conditions;

- the technology may be applied to companies producing non-woven textiles with technical use; currently only three such companies are active in the country, therefore entrepreneurial initiatives in this field are necessary and timely;

- newly created companies will contribute to the use of native resources of thick and semi-thick wools, implicitly in creating new jobs and attracting young people, especially in rural areas, where a depopulation phenomenon is currently occurring;

- the new products will contribute to the development and implementation of the concept of green houses with low construction and operating costs.

\section{CONCLUSIONS}

Under the conditions of increasing Romanian thick and semi-thick wools, their exploitation by producing nonwoven fabrics for efficient constructions, both in terms of construction costs and energy maintenance of buildings is a good opportunity.

The results will be disseminated in debates with representatives of sheep breeders, with the involvement of the Regional Development Agencies in the country and actors in the construction sector, in order to stimulate the regional entrepreneurial initiatives, both in non-woven textiles, and in the green building fields.

\section{ACKNOWLEDGEMENTS}

This paper was written with the support of 5PS/ 2017 research project financed by SECTORIAL PROGRAMME coordinated by ROMANIAN MINISTRY of RESEARCH and INNOVATION.

\section{BIBLIOGRAPHY}

[1] Strategy for Rural Sustainable Development in Romania 2014-2020.

[2] European Commission 2020, An European Strategy for Smart, Green and Inclusive Growth, http://eurex.europa. eu/LexUriServ/LexUriServ.do?uri=COM:2010:2020:FIN:RO:PDF.

[3] Romanian National Programme for Rural Development 2014-2020, www.fonduri-ue.ro/pndr-2014.

[4] Azra Korjenic, S.K. Sheep Wool. Construction Material for Energy Efficiency Improvement, Energies, 2015, pp. 5765-5781.

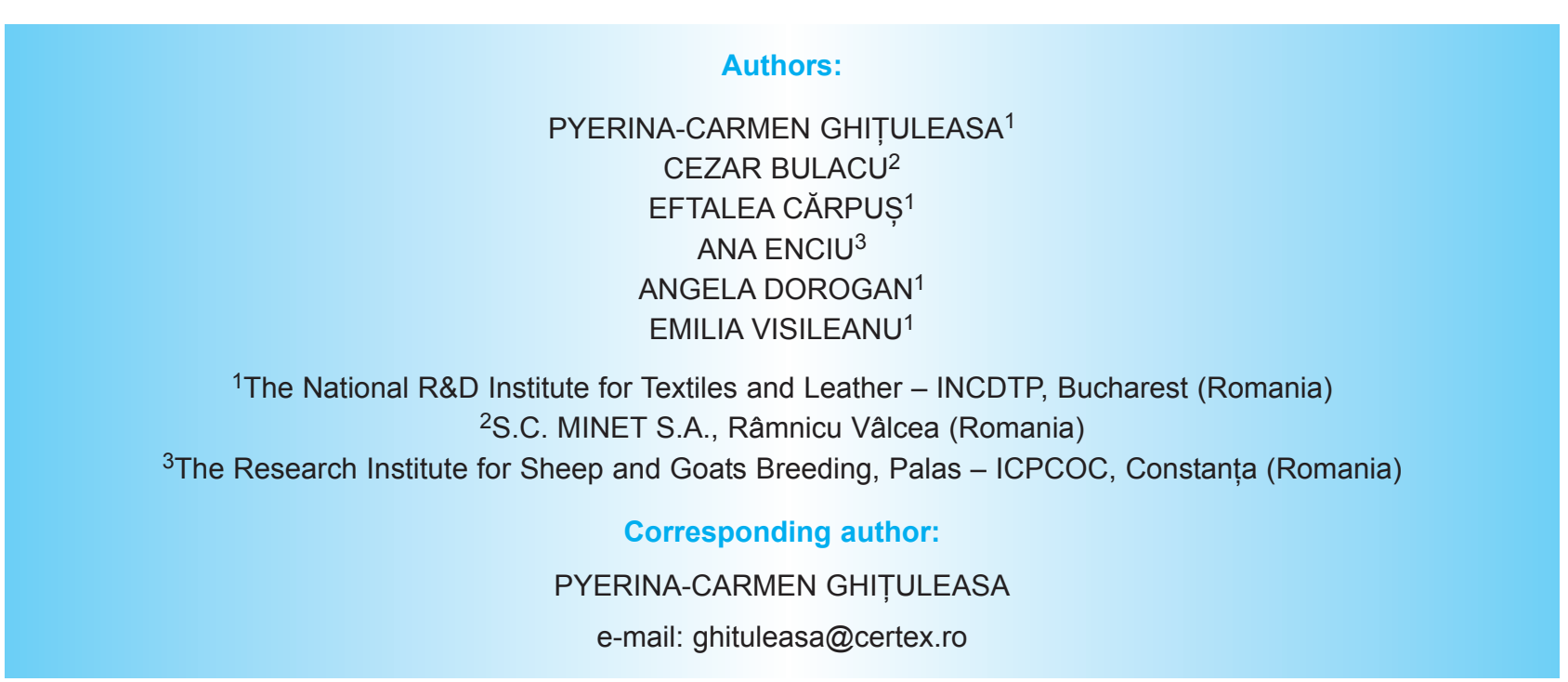

